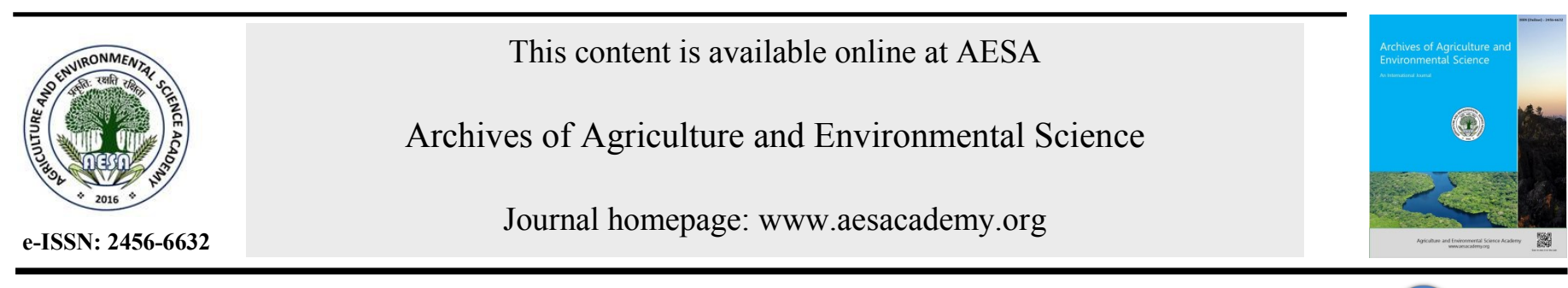

REVIEW ARTICLE

\title{
A review on sewage sludge (Biosolids) a resource for sustainable agriculture
}

\author{
Vinod Kumar $^{1 *}$, A.K. Chopra ${ }^{1}$ and Ajendra Kumar ${ }^{2}$ \\ ${ }^{1}$ Agro-ecology and Pollution Research Laboratory, Department of Zoology and Environmental Science, Gurukula Kangri \\ Vishwavidyalaya, Haridwar-249404 (Uttarakhand), INDIA \\ ${ }^{2}$ Department of Mathematics and Statistics, Gurukula Kangri Vishwavidyalaya, Haridwar-249404 (Uttarakhand), INDIA \\ *Corresponding author's E-mail: drvksorwal@gkv.ac.in
}

\section{ARTICLE HISTORY}

Received: 11 August 2017

Revised received: 16 October 2017

Accepted: 12 November 2017

\section{Keywords}

Agricultural uses

Biosolids

Biogas

Organic fertilizer

Sewage sludge

Soil amendment

Sustainable development

\begin{abstract}
Sewage sludge (Biosolids) generation is fastly increasing resulting from the regular increase of population, urban planning and industrial developments worldwide. The sludge needs to be adequately treated and environmentally managed to reduce the negative impacts of its application or disposal. The present review deals with the different applications of sewage sludge for sustainable agriculture. The scattered literature is harnessed to critically review the uses of biosolids to promote sustainable practices focusing on the productive uses of sewage sludge or biosolids. Biosolids or sewage sludge is the byproduct of municipal wastewater, sewage effluent and effluent treatment plants. The treatment plants are generating huge amount of biosolids. The present review focuses on the different applications of biosolids or sewage sludge as in many countries the biosolids or sewage sludge are frequently using for various purposes like for biogas production, land filling, organic fertilizer, soil amendment, and to enhance the crop yield of agricultural crops. Therefore, biosolids or sewage sludge is in the consideration as a resource worldwide. Besides this higher content of different heavy metals and microorganisms are the important constraints for the application of biosolids or sewage sludge in the various fields. Thus, this review emphasizes the different applications and possible limitations for the use of biosolids or sewage sludge as a resource. Efforts have been made on the possible pretreatment of biosolids or sewage sludge to make it more feasible for their applications. Therefore, different properties of biosolids or sewage sludge, their applications along with possible limitations have been discussed in the present review to formulate the biosolids or sewage sludge as a resource for the sustainable development.
\end{abstract}

C2017 Agriculture and Environmental Science Academy

Citation of this article: Kumar, V., Chopra, A.K. and Kumar, A. (2017). A review on sewage sludge (Biosolids) a resource for sustainable agriculture. Archives of Agriculture and Environmental Science, 2(4): 340-347, DOI: 10.26832/24566632.2017.020417

\section{INTRODUCTION}

Sewage sludge (also known as biosolids) is defined as the residual, semi-solid substance that is produced as a by-product during the sewage treatment of industrial or municipal wastewater (Kumar and Chopra, 2016a). More specifically, the sewage sludge is formed as the by-product of the different treatment stages of wastewater from domestic households, and sometimes it also includes industrial and commercial effluents (Williams, 2005). Generally, the terms biosolids and sewage sludge are often used interchangeably. The important physicochemical characteristics of sewage sludge or biosolids includes the specific gravity (1.0 equal to water), solids concentration as the relative fraction of solids and water in the slurry and sludge volume index (SVI). Generally, the physicochemical characteristics of the biosolods or sewage sludge include $20 \%$ content of the fat, 50 carbohydrate content (sugar, starch, and fiber), $30 \%$ to $40 \%$ content of organic matter, $3 \%$ total nitrogen, $1.5 \%$ total phosphorus, $0.7 \%$ total potassium content, $10 \%$ to $20 \% \mathrm{C} / \mathrm{N}$ ratio, high levels of heavy metal ions: $\mathrm{Cu}, \mathrm{Zn}$. The heat value $\left(\mathrm{H}_{\mathrm{o}}\right)$ of the dry sludge is about $12.000 \mathrm{~kJ} / \mathrm{kg}$. The $\mathrm{pH}$ of the sewage sludge is normally ranged $6.5-7.0$ as reported by $\mathrm{Xu}(2014)$.

Properly treated and processed, sewage sludge becomes biosolids which are nutrient-rich organic materials produced from wastewater treatment facilities (Kumar and Chopra, 2013; Kumar et al., 2016). Moreover, biosolids can be recycled and applied as fertilizer to improve and maintain productive soils and stimulate plant growth. The management practices of sewage sludge increases the usability of the sewage sludge or biosolids and reduces the harmful substances from the sewage sludge to prevent their discharge in the aquatic resources like rivers, lakes, streams etc. (Spinosa, 2008; Rogers, 2012).

The sewage sludge or biosolids generally varied in characteristics and contain organic and inorganic chemicals, toxic metals and pathogens. It is often considered as a resource due to the widespread application in soil amendment, energy generation, nutrient supply etc. The sewage sludge, having about $1 \%$ of wastewater when entering to the sewage treatment plant for the treatment, is digested anaerobically and resulted to remove the wastewater from the sludge. Sewage 
sludge, at the vent of production after mechanical drying, is having of almost $80 \%$ moisture and $20 \%$ dry matter. The sewage sludge have different organic and inorganic elements, small quantity of heavy metals such as iron (Fe), chromium $(\mathrm{Cr})$, manganese $(\mathrm{Mn})$, zinc $(\mathrm{Zn})$, mercury $(\mathrm{Hg})$, lead $(\mathrm{Pb})$, nickel $(\mathrm{Ni})$, cadmium $(\mathrm{Cd})$ and copper $(\mathrm{Cu})$ etc. These elements restrict the use of sludge in agriculture, because their accumulation is harmful to the environment and particularly to the food chain (Kumar and Chopra, 2012; Kumar and Chopra, 2016b).

The properties of sludge associated with the origin and amount of flushing water (public toilet, private toilet), its assortment type (on-site, off-site) and following treatment level, for example digestion. Fresh and untreated sludge will have many pathogens, a high proportion of water, high biochemical oxygen demand (BOD) and is normally putrid and odorous. Nevertheless, sludge also contains essential nutrients for plants (e.g. nitrogen and phosphorus) and is potentially a very beneficial fertilizer. The most important component like organic carbon in the sludge, once alleviated, has also capable as a soil conditioner because it likely improves soil structure for plant roots, or can be transformed into energy through bio-digestion or incineration. As sewage may receive harmful pollutants (e.g. heavy metals, pharmaceuticals) from industries and other activities which may accumulate in its sludge (Javier Mateo-Sagasta et al., 2015).

Generally, the sewage sludge resulting from primary and secondary water treatment. Before entering the digesters, the sludge is sometimes sieved and is then thickened to a dry solids content of up to $7 \%$ in order to avoid too high energy consumption for heating due to excessive water content. Preferably, the sludge can be pretreated by disintegration technologies with the goal to recover the biogas yield. The primary sludge, also called raw sludge, is produced by gravitational sedimentation in the primary sedimentation tank. It has a high content of organic matter and is easily degradable. Under optimum digestion conditions, a methane yield of $315-400 \mathrm{Nm}^{3} / \mathrm{t}$ organic dry matter (Zhang, 2010). The Secondary sludge, also called excess sludge or activated sludge, results from the biological treatment of wastewater. It has a lesser degradable fraction than primary sludge and as a result reduction in the biogas yield. Under optimum decomposable circumstances, a methane yield of $190-240 \mathrm{Nm}^{3} / \mathrm{t}$ organic dry matter (Zhang, 2010).

\section{GLOBAL SCENARIO OF SEWAGE SLUDGE GENERATION}

The global population is increasing and concentrating in urban centers. This trend is particularly intense in developing countries, where an additional 2.1 billion people are expected to be living in cities by 2030 (Xu, 2014; Javier Mateo-Sagasta et al., 2015). The sewage treatment plants also generate sludge (a semi solid substance), called sewage sludge, when suspended solids are removed from the wastewater and when soluble organic substances are converted to bacterial biomass which also becomes part of the sludge (Javier Mateo-Sagasta et al., 2015). Ning-Yi Wang et al. (2013) reported the emission quantity of greenhouse gases, land filling has the greatest impact $(296.9 \mathrm{~kg} \mathrm{CO}$ eq./t sludge), followed by monoincineration (232.2 $\mathrm{kg} \mathrm{CO}$ eq./t sludge) and carbonization (146.1 kg CO 2 eq./t sludge). Co-incineration with municipal solid waste has the benefit of reducing green house gas emission (-15.4 $\mathrm{kg} \mathrm{CO}$ eq./t sludge). Consequently, the carbonization would be a quite beneficial method of sewage sludge if the energy generation, distribution and integration processes are made more competent.

\section{INDIAN SCENARIO OF SEWAGE SLUDGE GENERATION}

According to Central Pollution Control Board (CPCB), New Delhi, about 38354 million liter per day (MLD) wastewater generated from cities and towns is the main cause of freshwater pollution in India (CPCB, 2009). A nearly less than half of this quantity only about 11786 MLD is treated by the sewage treatment plants (STPs) and rest of the sewage is discharged without treatment. Therefore, almost all the water bodies including lakes, ponds wetlands, streams, rivers and their catchments areas are severely polluted due to the discharge of untreated or partially treated sewage effluent (Bhardwaj, 2005; CWC, 2012). Additionally, these conditions are also responsible for the outbreak of a number of water borne as well as food borne diseases in these proximities (CGWB, 2011; CWC, 2012). Similarly, the sewage sludge generated during the treatment of sewage effluent is dried in the sludge beds and using for fertilize the agricultural crops (CPHEEO, 2012). In India characteristically, the sewage sludge contained total nitrogen (15400-1920 mg Kg${ }^{-1}$ ), available nitrogen (4600 $-6300 \mathrm{mg} \mathrm{Kg}^{-1}$ ), available phosphorus (44-60 $\mathrm{mg} \mathrm{Kg}^{-1}$ ) and available potassium (290-410 $\left.\mathrm{mg} \mathrm{Kg}^{-1}\right)$. Besides this higher contents of different heavy metals like arsenic (8-23 $\left.\mathrm{mg} \mathrm{Kg}^{-1}\right)$, $\mathrm{Cd}$ (2-9 mg Kg$\left.{ }^{-1}\right), \mathrm{Cr}\left(66-1098 \mathrm{mg} \mathrm{Kg}^{-1}\right), \mathrm{Hg}$ (7-32 mg Kg${ }^{-1}$ ), $\mathrm{Ni}$ (12-596 mg Kg$\left.{ }^{-1}\right)$ and $\mathrm{Pb}\left(26-154 \mathrm{mg} \mathrm{Kg}^{-1}\right)$ were reported by Dubey et al. (2006). Kumar and Chopra (2013) and Kumar et al. (2016) also reported higher contents of nutrients and heavy metals in the municipal sewage sludge.

\section{SEWAGE SLUDGE AS RESOURCE}

During the past years, waste minimization and recycling/reuse policies have been introduced so as to reduce the amount of waste generated and alternative waste management strategies are being exploited, to reduce the environmental impacts of waste management (IPCC, 2006). Notwithstanding, sewage sludge represents a source of material, energy and nutrients, it is possible to utilize it as raw material for industrial production, energy production and soil amendment. There exist several processes through which sewage sludge can be converted into useful output and this includes coincineration and monoincineration with energy recovery, anaerobic digestion with biogas production and aerobic composting, pyrolysis, gasification and wet oxidation processes. The selection of a sewage sludge management method or technique from the accessible options should be based on their environmental effect that is which technology creates less impact on the environment. As per the public attention on the environmental effects of the management choices selected for sewage sludge treatment increases, industries are beginning to accept the clean technology approach and assessment of environmental impacts of alternative processes, in process evaluation (Poulsen and Hansen, 2003).

Many countries have recently recognized that sewage sludge components can be recycled in a "Productification" strategy which is aimed at making products from sludge which are intended for sale in the market place. Sludge based products can be used for energy and also reused with matter recovery for land application. According to the "Productification" strategy, these products could be used not only on-site, such as at the treatment plants, as has been practiced for many years, but can be sold in the open market as well (Spinosa, 2008; Rogers, 2012). There is a wide range of uses for sewage 
sludge that exploit its nutrient, material and energy contents, for instance, drying, incineration, composting, anaerobic digestion, and so on. Among these processes, sludge composting and anaerobic digestion have been receiving more and more attention in terms of their marketable products (BioTEnMaRe, 2014). Biogas technology is one of the options for deployment in conversion of organic residues to

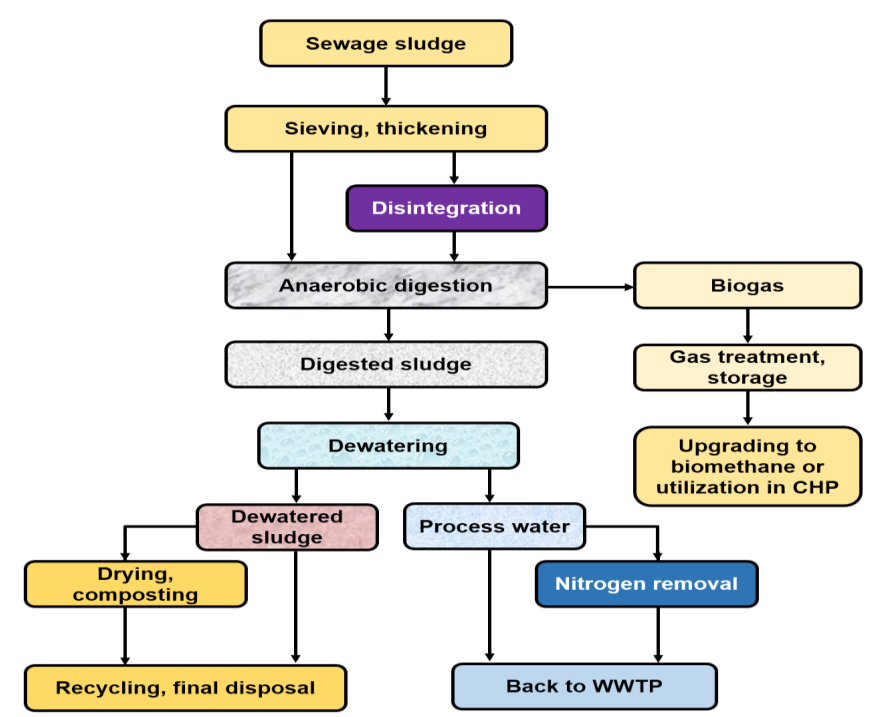

Figure 1. Diagrammatic sketch of sewage sludge production and possible resource recovery (Source: Bachmann, 2015; modified by the authors).

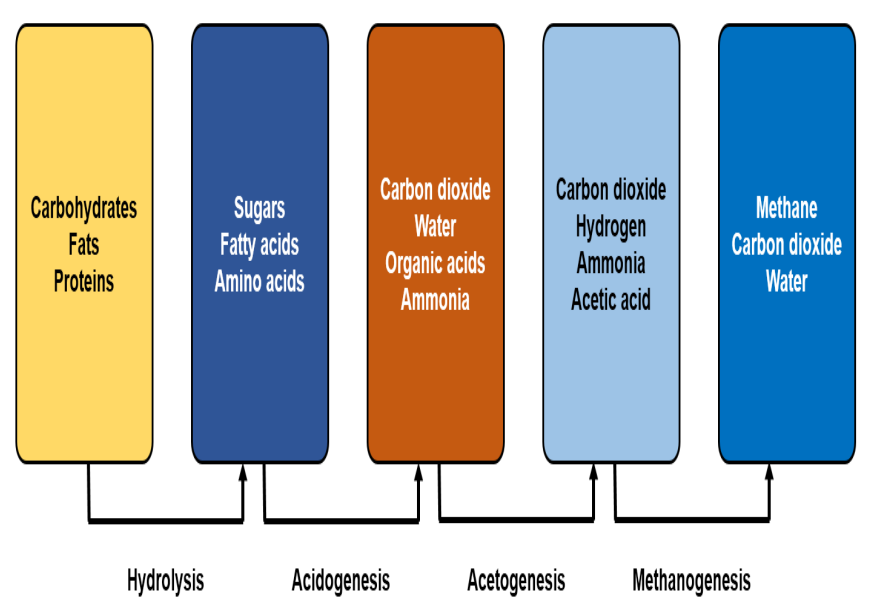

Figure 3. Process of aerobic digestion (Source: Williams 2005; modified by the authors).

\section{SEWAGE SLUDGE MANAGEMENT PRACTICES}

Sewage sludge composting: Sludge composting occurs via an aerobic bacterial decomposition process that stabilizes the organic substances in sludge and produces compost (humus). The overall chemical reaction of composting is (Finstein et al., 1980):

$\mathrm{C}_{10} \mathrm{H}_{19} \mathrm{O}_{8} \mathrm{~N}+12.5 \mathrm{O}_{2} \rightarrow 10 \mathrm{CO}_{2}+8 \mathrm{H}_{2} \mathrm{O}+\mathrm{NH}_{3}$

The sludge composting aims to biologically stabilize sludge and control pollution risks, in order to develop agriculture or other end use outlets based on the nutritional or organic value (Bresters, 1997).

Sewage sludge in biogas production: The sewage sludge may be utilized for the generation and recovery of the energy, if adequately dry directly, by incineration or, indirectly, using anaerobic digestion, pyrolysis or gasification, that generate bio-fuels such as methane-rich biogas, bio-oil and syngas renewable energy and valuable fertilizer. In Figure 1 provide an outline for the generation, recovery of sewage sludge production and possible resource recovery and also suggest the mechanism and strategy for the sewage sludge management. Figure 2 shows the various methods for waste management which can be implemented for the uses of sewage sludge for sustainable agriculture.

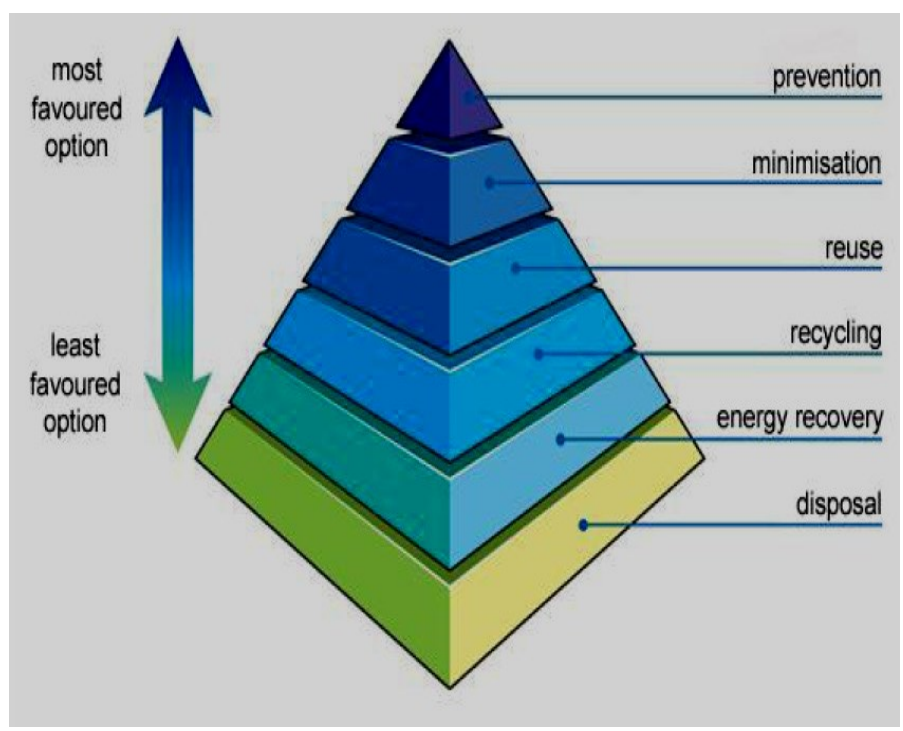

Figure 2. The most suitable methods for waste management (Source: Akwo, 2008).

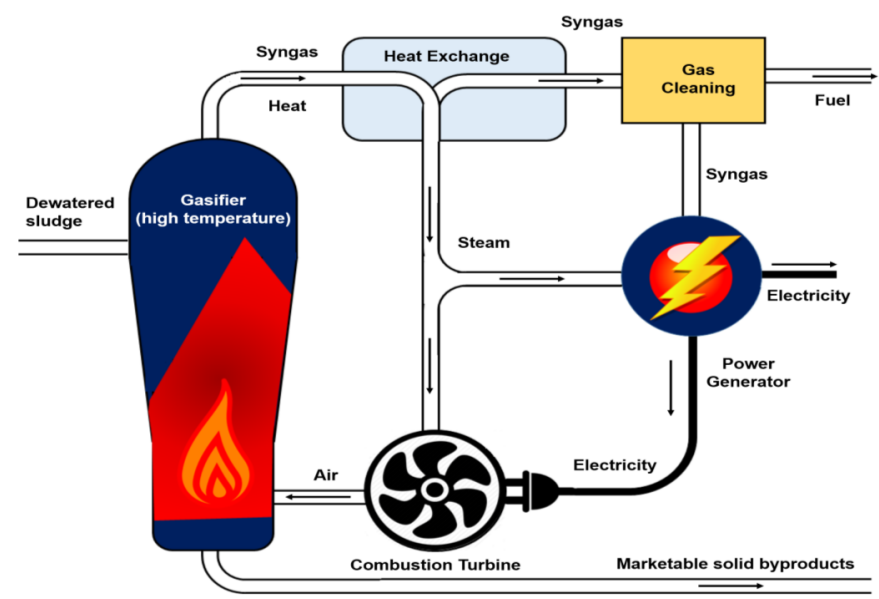

Figure 4. Process of gasification (Source: Baily, 2009; modified by the authors).

(Kalogo and Monteith, 2012). A mechanism has been provided in the Figure 3 for the effective aerobic digestion of the sewage sludge. The energy content in products for energy use and energy content in raw sludge are two important elements for the estimating of energy recovery efficiency. However, the dried sludge becomes a valuable and renewable energy source with a calorific value similar to lignite (Bachmann, 2009). Pöschl et al. (2010) suggested that, whereas the upgrading of biogas to biomethane for injection into natural gas network potentially increased the primary energy input for biogas utilization by up to $100 \%$; the energy effectiveness of the biogas production method must be improved by up to $65 \%$ when natural gas was substituted in place of electricity. It was noticeable that, the effectiveness of the system energy could be additionally enhanced by $5.1-6.1 \%$ by using recovery of the residual biogas from the enclosed digestate storage units. The biogas produced from sewage sludge or biosolids is a 
clean and renewable energy source. It is an ideal fuel for combined heat and power applications. The biogas can be produced with anaerobic bacteria or fermentation of biodegradable materials. The heat value of it is $21-25 \mathrm{MJ} / \mathrm{m}^{3}$ (with an average concentration of $\left.65 \% \mathrm{CH}_{4}\right)$ and $30-40 \%$ lower than natural gas $\left(37.3 \mathrm{MJ} / \mathrm{m}^{3}\right)(\mathrm{Xu}, 2014)$. Anaerobic digestion is a bacterial decomposition process in the absence of oxygen that stabilizes organic wastes and produces biogas, a mixture of methane and carbon dioxide. The heat value of methane is about similar to natural gas, therefore biogas is considered as a valuable energy resource (Halls, 2000). There are four key biochemical stages in anaerobic digestion, which are hydrolysis, acidogenesis, acetogenesis and methanogenesis (Williams, 2005; Kumar et al., 2017).

Hydrolysis is the first stage in the decomposition of macromolecular substances such as carbohydrates, fats and proteins (Figure 3). Afterwards some low-molecular substances arise from hydrolytic bacteria activities, such as sugars, fatty acids and amino acids (Baily, 2009). Acidogenesis is the second stage in which products of hydrolysis are decomposed by fermentation bacteria into organic acids, carbon dioxide, water, and sometimes ammonia. The main reaction equation is (Baily, 2009):

$\mathrm{C}_{6} \mathrm{H}_{12} \mathrm{O}_{6} \rightarrow \mathrm{CH}_{3}\left(\mathrm{CH}_{2}\right)_{2} \mathrm{COOH}+2 \mathrm{CO}_{2}+2 \mathrm{H}_{2} \mathrm{O}$

Acetogenesis and methanogenesis usually run simultaneously (Figure 3). The former uses bacteria to decompose organic acids into acetic acid and hydrogen. The latter uses methanogenic bacteria to further decompose acetic acid into methane and carbon dioxide, at the same time more methane is created from hydrogen and carbon dioxide by another type of methanogenic bacteria. The reaction equations are (Baily, 2009):

$$
\begin{aligned}
& \mathrm{CH}_{3}\left(\mathrm{CH}_{2}\right)_{2} \mathrm{COOH}+2 \mathrm{H}_{2} \mathrm{O} \rightarrow 2 \mathrm{CH}_{3} \mathrm{COOH}+2 \mathrm{H}_{2} \\
& 2 \mathrm{CH} 3 \mathrm{COOH} \rightarrow \mathrm{CH}_{4}+\mathrm{CO}_{2} \\
& 4 \mathrm{H}_{2}+\mathrm{CO}_{2} \rightarrow \mathrm{CH}_{4}+2 \mathrm{H}_{2} \mathrm{O}
\end{aligned}
$$

Gasification is a thermal process that can convert organic based sludge materials with air (Sometimes oxygen or steam) into an inflammable gas (Baily, 2009). A diagrammatic sketch shown in Figure 4 has been suggested by Baily (2009) for the gasification of sewage sludge.

$$
\begin{aligned}
& \mathrm{C}+\mathrm{CO}_{2} \rightarrow 2 \mathrm{CO} \\
& \mathrm{C}+\mathrm{H}_{2} \mathrm{O} \rightarrow \mathrm{CO}+\mathrm{H}_{2} \\
& \mathrm{CO}+3 \mathrm{H}_{2} \rightarrow \mathrm{CH}_{4}+\mathrm{H}_{2} \mathrm{O}
\end{aligned}
$$

Sewage sludge in soil amendment: The sewage sludge may be processed using different methods for the reduction of pathogens in the sewage sludge. The important methods are aerobic digestion of the sludge, air drying of sludge, anaerobic digestion, composting, and lime stabilization of the sewage sludge (EPA, 1995). Moreover, in air drying method of sewage sludge, the sewage sludge is dried for months or more on sludge drying beds of sand or paved basins of sludge dryness (EPA, 1985, 1995). Therefore, using the composting method, the sewage sludge is preserved either within a static aerated vessel or windrow composting methods (EPA, 1995), whereas, in the lime stabilization method, the sewage sludge is mixing with lime to increase the $\mathrm{pH}$ of the sewage sludge (EPA, 1995).

The sewage sludge can be made utilizable through the land application, and for this the wastewater treatment facility needs to put the sewage sludge into a biosolids form. Currently there are six different categories of sewage sludge or biosolids produced that can be utilized in the land application, liquid, dewatered, air-dried, alkaline-treated, composted, and heat-dried (EPA, 1985; Walker, 1994). The dewatered form of the sewage sludge can be stabilized by the application of three procedures as aerobic digestion which resulting in 2 to $5 \%$ nitrogen content; anaerobic digestion results in 2 to $5 \%$ nitrogen content; and lime stabilization resulting in 1 to $3 \%$ nitrogen content (Walker, 1994). The alkaline-treated sewage sludge or biosolids can be stabilized in two different methods as a process through kiln dust resulting in 1 to $2 \%$ nitrogen content and a procedure lacking kiln dust resulting in 1 to $2 \%$ nitrogen content (Walker, 1994). The air-dried form of the sewage sludge can be stabilized in three methods as the aerobic digestion which is resulting in 2 to $4 \%$ nitrogen content; second is the anaerobic digestion that results in 2 to $4 \%$ nitrogen content; and the third one is the lime stabilization which is resulting in 1 to $3 \%$ nitrogen content (Walker, 1994). The composted form of the sewage sludge might be stabilized in many differences of agitated and static aerated procedures in and out of vessels, resulting in 1 to $2 \%$ nitrogen content (EPA, 1985; Walker, 1994).

The application of biosolids increases soil microbial biomass and some soil enzymatic activities such as urease, alkaline phosphatase and $\beta$-glucosidase linked to $\mathrm{C}, \mathrm{N}, \mathrm{P}$ and $\mathrm{S}$ soil cycles (Liang et al., 2003; Tejada et al., 2006). Liang et al. (2005) also reported that the incorporation of organic amendments to soil stimulate dehydrogenase activity because the added material may contain intra- and extracellular enzymes and may also stimulate microbial activity in the soil. Tejada et al. (2006) and Walker and Bernal (2008) found that the compost or Sewage sludge was effective for the remediation of the saline soil. Abdelbasset et al. (2010) reported that the use of municipal solid waste compost (13.3 $\left.\mathrm{g} \mathrm{Kg}^{-1}\right)$ and sewage sludge (26.6 $\mathrm{g} \mathrm{Kg}^{-1}$ ) significantly improved soil physicalchemical properties, especially carbon and nitrogen contents. Accordingly, overall enzyme activities were substantially promoted in presence of both amendments and the higher increases were measured at $13.3 \mathrm{~g} \mathrm{Kg}^{-1}$ of municipal solid waste compost (increases by $107 \%, 43 \%, 20 \%, 11 \%$, and $148 \%$ for, DEH, $\beta$-GLU, PHO, URE, and CAT, respectively). Therefore, a number of scientists have reported the application of sewage sludge or biosolids for the soil amendment or to fertilize the soil for sustainable agriculture.

Use of sewage sludge in agriculture: The application of sewage sludge is found to be very productive for the agricultural crops yield. According to Franz (2008) sewage sludge incineration are rich in phosphorus content, ranging between $4 \%$ and $9 \%$ and about $90 \%$ of phosphorus can be extracted from sewage sludge ash (SSA) to make an adequate phosphate fertilizer. About $37 \%$ of sewage sludge produced is actually applied to agricultural land; other main pathways are land reclamation and restoration $(12 \%)$ and incineration $(11 \%)$ as reported by Fytili et al. (2008). Lundin et al. (2004) concluded that two sludge handling options, incineration and direct application to agricultural soil, have respectively economic and environmental restrictions. The development of relatively low cost phosphorus recovery technologies has the potential to reconcile the environmental and economic aspects of sustainability. During the recent past, a number of researchers reported the application of sewage sludge in the soil amendment and cultivation of agricultural crops globally (Table 1). The research reports clearly indicated that the use of sewage sludge enhance the overall growth and yield of agricultural crops and reduce the application of chemical or synthetic fertilizers. 
Table 1. Toxic chemicals and heavy metals in different crops and soils due to the use of sewage sludge.

\begin{tabular}{|c|c|c|}
\hline $\begin{array}{l}\text { Chemical species as heavy } \\
\text { metal / Other toxic element }\end{array}$ & Crop/soil type/soil location & References \\
\hline DTPA, Cd, Zn and Mn & Ultisol (red clay soils) and vertisol & Ramachandran and D'Souza (1998) \\
\hline $\mathrm{Cu}, \mathrm{Zn}, \mathrm{Pb}, \mathrm{Ni}, \mathrm{Cr}, \mathrm{Cd}$ & Chhatarpur and Badarpur & Shrivastava and Banerjee (2003) \\
\hline $\mathrm{Cd}, \mathrm{Zn}, \mathrm{Cu}$ & $\begin{array}{l}\text { Seeds of leaf beet } \\
\text { (perpetual spinach, Beta vulgaris, Cicla) }\end{array}$ & Datta and Young (2004) \\
\hline $\mathrm{Zn}, \mathrm{Cu}, \mathrm{Mn}, \mathrm{Ni}, \mathrm{Cd}, \mathrm{Mo}$ & Red clover plant & McBride et al. (2004) \\
\hline $\mathrm{Cd} \mathrm{Cr} \mathrm{Cu} \mathrm{Mn} \mathrm{Ni} \mathrm{Pb} \mathrm{Zn}$ & Soil treated with sewage sludge compost & Selivanovskaya et al. (2004) \\
\hline $\begin{array}{l}\mathrm{K}, \mathrm{Ca}, \mathrm{Mg}, \mathrm{Zn}, \mathrm{Mn}, \mathrm{Cu}, \mathrm{Fe}, \mathrm{Al} \\
\text { and } \mathrm{Na}\end{array}$ & South Florida, USA & Sigua et al. (2005) \\
\hline $\mathrm{Zn}, \mathrm{Fe}, \mathrm{Pb}, \mathrm{Cd}, \mathrm{Zn}, \mathrm{Fe}, \mathrm{Pb}, \mathrm{Cd}$ & Fennel plants shoot & $\begin{array}{l}\text { El-Motaium and Abo El-Seoud } \\
(2007)\end{array}$ \\
\hline $\mathrm{Cd}, \mathrm{Cr}, \mathrm{Cu}, \mathrm{As}, \mathrm{Ni}, \mathrm{Pb}, \mathrm{Zn}$ & Sorghum bicolor (L.) & Jamali et al. (2008) \\
\hline $\mathrm{Cd}$ & $\begin{array}{l}\text { Indian mustard, } \\
\text { Cabbage and cauliflower, }\end{array}$ & Sikka et al. (2009) \\
\hline $\mathrm{Cd}, \mathrm{Pb}, \mathrm{Cr}, \mathrm{Ni}, \mathrm{Cu}, \mathrm{Zn}$ & Potato & Pakhnenkoa et al. (2009) \\
\hline $\begin{array}{l}\mathrm{Fe}, \mathrm{Cr}, \mathrm{Cu}, \mathrm{Mn}, \mathrm{Ni}, \mathrm{Zn}, \mathrm{Cd}, \mathrm{Pb} \\
\mathrm{Mg}, \mathrm{Na}, \mathrm{K}, \mathrm{P}, \mathrm{N}\end{array}$ & Pinus radiata & Rodri'guez et al. (2010) \\
\hline $\mathrm{Cu}, \mathrm{Zn}, \mathrm{Ni}, \mathrm{Cd}, \mathrm{Cr}, \mathrm{Pb}$ & Brassica juncea (Root and shoot) & Dede et al. (2012) \\
\hline $\mathrm{Cd}, \mathrm{Cr}, \mathrm{Ni}$ & $\begin{array}{l}\text { Radish, Turnip, Carrot, Potato, Tomato, Bean, Cauliflower, } \\
\text { Brinjal, Cabbage, Spinach, Coriander }\end{array}$ & Amlan et al. (2012) \\
\hline $\mathrm{Cu}, \mathrm{Fe}, \mathrm{Mn}, \mathrm{Zn}$ & Tropical soils & Nogueirol et al. (2013) \\
\hline $\mathrm{Fe}, \mathrm{Zn}, \mathrm{Cd}, \mathrm{Cu}, \mathrm{Pb}, \mathrm{Cr}$ & $\begin{array}{l}\text { French Bean (Phaseolus vulgaris L.) (Shoot, root, leaves, } \\
\text { fruit) }\end{array}$ & Kumar and Chopra (2014) \\
\hline $\mathrm{Pb}, \mathrm{Cr}, \mathrm{Cd}, \mathrm{Cu}, \mathrm{Zn}, \mathrm{Ni}$ & Cabbage & Ullah and Khan (2015) \\
\hline $\mathrm{Zn}, \mathrm{Cu}, \mathrm{Ni}, \mathrm{Cr}$ & $\begin{array}{l}\text { Sunflower (Helianthus annuus) } \\
\text { (Shoots and roots) }\end{array}$ & Belhaj et al. (2016) \\
\hline $\mathrm{Cd}, \mathrm{Pb}$ and $\mathrm{Zn}$ & Shoots of Salix and Populus & Kubátová et al. (2016) \\
\hline $\begin{array}{l}\mathrm{Zn}, \mathrm{Cu}, \mathrm{Fe}, \mathrm{Mn}, \mathrm{Ni}, \mathrm{Pb} \\
\mathrm{Cd}, \mathrm{Cr}, \mathrm{As}\end{array}$ & Rice grain & Meena et al. (2016) \\
\hline $\mathrm{Cu}, \mathrm{Zn}, \mathrm{Cr}, \mathrm{Ni}, \mathrm{Cd}, \mathrm{Pb}$ & Sugarcane (leaf and juice) & Leite Moretti et al. (2016) \\
\hline $\begin{array}{l}\mathrm{Fe}, \mathrm{Mn}, \mathrm{Cu}, \mathrm{Zn}, \mathrm{Cd}, \mathrm{Ni}, \mathrm{Pb}, \mathrm{Co}, \\
\mathrm{Cr}, \mathrm{Ca}, \mathrm{Mg}, \mathrm{Na}, \mathrm{K}, \mathrm{Cl}, \mathrm{N}, \mathrm{P} \\
\text { SO4 }\end{array}$ & Tomato & Alghobar and Suresha (2017) \\
\hline $\mathrm{Zn}, \mathrm{Cu}, \mathrm{Mn}, \mathrm{Ni}, \mathrm{Pb}, \mathrm{Cd}, \mathrm{Cr}$ & $\begin{array}{l}\text { Clay loam and clay loam soil of Thessaloniki Plain } \\
\text { (Greece) }\end{array}$ & Tziachris et al. (2017) \\
\hline $\mathrm{Pb}, \mathrm{Cr}, \mathrm{Cd}, \mathrm{Cu}, \mathrm{Zn}, \mathrm{Ni}, \mathrm{Fe}, \mathrm{Mn}$ & $\begin{array}{l}\text { Spinacia oleracea, Brassica oleracea var. capitate, Brassica } \\
\text { oleracea var. botrytis, Raphanus sativus, Brassica rapa } \\
\text { subsp. Rapa, Benincasa fistulosa, Daucus carota subsp. } \\
\text { Sativus, Lactuca, Colocasia esculenta }\end{array}$ & Ullah et al. (2017) \\
\hline $\mathrm{Cu}, \mathrm{Zn}, \mathrm{Cd}, \mathrm{Pb}, \mathrm{Fe}, \mathrm{Mn}$ & Wheat plant (Triticum aestivum L.) & Shahbazi et al. (2017) \\
\hline $\begin{array}{l}\mathrm{Fe}, \mathrm{Pb}, \mathrm{Zn}, \mathrm{Mn}, \mathrm{Cr}, \mathrm{Cu}, \mathrm{Ni}, \mathrm{Co} \text {, } \\
\mathrm{Cd}\end{array}$ & Cucumbers (Cucumis sativus L.) & Eid et al. (2017) \\
\hline
\end{tabular}

\section{CONSTRAINTS}

In most of the time the generated sewage sludge or biosolids is applied, disposed or discharged lacking of any satisfactory treatment. Therefore, it may pose serious environmental and public health impacts (Turovskiy and Mathai, 2006; Hong et al., 2009). Moreover, due to the continuous rapid growing population, the sewage sludge generation is expected to increase significantly in the future. Sewage sludge has potential to contain pollutants and particular metals (Arlt et al., 2002; Ghazy et al., 2009). Moreover, different researchers have reported the presence of toxic chemicals as heavy metals in the soil and various crops due to the application of sewage sludge in agriculture (Table 1).
Exclusive of analysis, it is difficult to enlighten what kind of heavy metals and other pollutants exist in sewage sludge and if the contaminants exist at levels of concern (Clapp et al., 1994). Early users of sewage sludge did not know of the pollutants that existed in the sewage sludge, and how to lower or remove the pollutants to safe levels and this perceptive of sewage sludge resulted in avoidance of sewage sludge as a land amendment (Lue-Hing et al., 1994; Turovskiy and Mathai, 2006; Hong et al., 2009). Eljarrat et al. (2008) reported the significant content of Polybrominated diphenyl ethers (PBDE) in sewage sludge ranged from 197 to $1185 \mathrm{ng} / \mathrm{g}$ dry weight $(\mathrm{dw})$ and further in the sewage sludge amended soil PBDE levels in soils ranged between 21 and $690 \mathrm{ng} / \mathrm{g} \mathrm{dw}$. Moreover, levels about $200 \mathrm{ng} / \mathrm{g} \mathrm{dw}$ have been reported in 
sludge from Sweden and The Netherlands (Sellstrom et al., 1999; de Boer et al., 2002), and around $500 \mathrm{ng} / \mathrm{g} \mathrm{dw}$ for samples collected in Denmark (Christenson et al., 2003). Higher concentrations were found in USA, with values ranging from 1000 to $2290 \mathrm{ng} / \mathrm{g} \mathrm{dm}$ for tri- to hexa-BDEs, and from 85 to $4890 \mathrm{ng} / \mathrm{g} \mathrm{dm}$ for deca-BDE-209, with the mean values of approximately 1600 and $1000 \mathrm{ng} / \mathrm{g}$, respectively (Hale et al., 2003).

The use of biosolids in agriculture is strictly regulated in developed countries but can be encouraged like in Michigan's biosolid and septage programs. Reuse is driven by the intention of closing nutrient loops to ensure that nutrients are returned to agricultural land to improve soil fertility while reducing the pressure on final deposal sites. However, in many developed and industrialized nations, there is a rising obstruction for the application of the sewage sludge or biosolids in the agriculture, due to the anxieties regarding the possible content of persistent and toxic pollutants such as pathogens and heavy metals. In these countries energy recovery from sludge, mainly through bio-digestion and incineration, is gaining momentum (Javier Mateo-Sagasta et al., 2015). Most importantly, although the application of sewage sludge in soil amendment or to fertilize the soil by supplying the essential nutrients significantly affected the growth and crop yield but on the other hand it enhance the chances of contamination of heavy metals and pathogens of agricultural soil and crops.

\section{Conclusions}

The literature harnessed in the present review concluded that the biosolids or sewage is effectively using for various purposes. It is playing a significant role in energy generation, soil amendment and crop production etc. Whereas there are certain drawback for their use as the applications of sewage sludge or biosolids among developing countries are likely to be significantly different in developed countries. Therefore, sludge or biosolids should be sampled and checked for contaminants (pathogens, heavy metals etc) before use in soil amendment and agriculture and other applications. Moreover, the uses of biosolids or sludge should be based on regular monitoring, frequency of sampling and analysis depends on the production and quality of the sludge. Most efficient sludge management strategy should be made with main focus on economic, technological and societal constraints; however, assessment of the overall sustainability of sludge management is now becoming an important aspect for the scientists, researchers and policy makers in decision-making for sustainable development in the future. Therefore, more scientific research should be required on the different aspects of biosolids or sewage sludge to make it more feasible resource for the sustainable development.

Open Access: This is open access article distributed under the terms of the Creative Commons Attribution License, which permits unrestricted use, distribution, and reproduction in any medium, provided the original author(s) and the source are credited.

\section{REFERENCES}

Abdelbasset Lakhdar, Rosalia Scelza, Riccardo Scotti, Maria A. Rao, Naceur Jedidi, Liliana Gianfreda, and Chedly Abdelly (2010). The effect of compost and sewage sludge on soil biologic activities in salt affected soil. Revista de la Ciencia del Sueloy Nutrición Vegetal, 10(1): 40-47.

Akwo, N.S. (2008). A life cycle assessment of sewage sludge treatment options. Department of Development and Planning Aalborg University.
Alghobar, M.A. and Suresha, A. (2017). Evaluation of metal accumulation in soil and tomatoes irrigated with sewage water from Mysore city, Karnataka, India. Journal of the Saudi Society of Agricultural Sciences, 16: 49-59.

Amlan, Kr., Ghosh, Bhatt, M.A. and Agrawal, H.P. (2012). Effect of long-term application of treated sewage water on heavy metal accumulation in vegetables grown in Northern India. Environmental Monitoring and Assessment, 184:1025-1036.

Arlt, A., Seifert, H., Nieke, E. and Furniss, B. (2002). Processing of sewage sludge for energetic purposes- a challenge for process technology. Bioprocessing of Solid Waste \& Sludge, 2: 19-29.

Bachmann, N. (2015). Sustainable biogas production in municipal wastewater treatment plants. IEA Bioenergy, ENVI Concept Route de Chambovey 2CH-1869 Massongex, Switzerland. Retrieved from http://www.iea-biogas.net on 30 July 2016.

Baily, R.E. (2009). Sludge Types, Treatment, Process and Disposal. USA, NOVA.

Belhaj, D., Elloumi, N., Jerbi, B., Zouari, M. Abdallah, F.B., Ayadi, H. and Kallel, M. (2016). Effects of sewage sludge fertilizer on heavy metal accumulation and consequent responses of sunflower (Helianthus annuus). Environmental Science and Pollution Research, 23: 20168-20177.

BioTEnMaRe (2014). BioTEnMaRe. from http:// www.biotenmare.com/.

Bhardwaj, R.M. (2005). Status of wastewater generation and treatment in India, IWG-Env Joint Work Session on Water Statistics, Vienna, 20-22 June 2005. https://unstats.un.org/unsd/ environment/envpdf/waterfinalagenda.pdf.

Bresters, A.R. (1997). Sludge treatment and disposal management approaches and experiences. Netherland, ISWA.

Christenson, J.H., Groth, B.S., Vikelsoe, J. and Vorkamp, K. (2003). NERI technical report No. 481.

Clapp, C.E., Larson, W.E. and Dowdy, R.H. (1994). Sewage sludge: Land utilization and the environment. American Society of Agronomy, Inc., Crop Science Society of America, Inc., Soil Science Society of America, Inc. Madison.

CGWB (2011). Ground water year book - India 2010-11. Central Ground Water Board, Ministry of Water Resources. Government of India. http://www.cgwb.gov.in/documents/ Ground\%20Water\%20Year\%20Book-2010-11.pdf.

CPHEEO (2012). Manual on sewerage and sewage treatment, Part A: Engineering Final Draft, Central Public Health and Environmental Engineering Organisation, Ministry of Urban Development, New Delhi.

CPCB (2009). Status of water supply, wastewater generation and treatment in Class I cities and Class II towns of India. Series: CUPS/70/2009-10. Central Pollution Control Board, India.

CWC (2012). Water and related statistics. Water Planning and Project Wing, Central Water Commission, India.

Datta, S.P. and. Young, S. D. (2005). Predicting metal uptake and risk to the human food chain from leaf vegetables grown on soils amended by long-term application of sewage sludge. Water, Air, and Soil Pollution, 163: 119-136.

de Boer, J., Allchin, C., Zegers, B., Boon, J.P., Brandsma, S.H., Morris, S., Kruijt, A.W., van der Veen, I., van Hesselingen, J.M., and Haftka, J.J.H. (2002). Emerging organic contaminants in sludges: Analysis fate and biological treatment, RIVO Rapport Number C033/02.

Dede, G., Ozdemir, S. and Dede, O.H. (2012). Effect of soil amendments on phytoextraction potential of Brassica juncea growing on sewage sludge. International Journal of Environmental Science and Technology, 9: 559-564.

Dubey, S.K., Yadav, R.K., Chatuvedi, P.K., Goyel, B., Yadav, R. and Minhas, P.S. (2006). Agricultural uses of sewage sludge and water and their impact on soil water and environmental health in Haryana, India. Abstract of 18th World Congress of Soil Science, Philadelphia, 9-15 July 2006.

Eid, E.M., Alrumman, S.A., El-Bebany, A.F., Hesham, A.E.L., Taher, M.A. and Fawy, K.F. (2017). The effects of different sewage sludge amendment rates on the heavy metal bioaccumulation, growth and biomass of cucumbers (Cucumis sativus L.). Environmental Science and Pollution Research, 24:16371- 
16382.

Eljarrat, E., Marsh, G., Labandeira, A., and Barcelo, D. (2008). Effect of sewage sludges contaminated with polybrominated diphenylethers on agricultural soils. Chemosphere, 71 10791086.

El-Motaium, R.A. and Abo El-Seoud, M.A. (2007). Irradiated sewage sludge for production of fennel plants in sandy soil. Nutrient Cycling in Agroecosystem, 78:133-142.

EPA (1985). Handbook Estimating Sludge Management Costs. EPA/625/6-85/010. U.S. Environmental protection agency, Cincinnati, Ohio.

EPA (1995). http//www.epa.gov/ORD/WebPubs/Landap.html> September 1995. Retrieved on October, 2000.

Finstein, M. S., et al. (1980). Engineering principles of sludge composting. USA, Water Pollution Control Federation.

Franz, M. (2008). Phosphate fertilizer from sewage sludge ash (SSA). Waste Management, 28(10): 1809-1818.

Fytili, D., and Zabaniotou, A. (2008). Utilization of sewage sludge in EU application of old and new methods - A review. Renewable and Sustainable Energy Reviews, 12, 116-140.

Ghazy, M., Dochorn, T., and Dichtl, N. (2009). Sewage sludge management in Egypt: Current status and perspectives towards a sustainable agricultural use. World Academy of Science, Engineering and Technology, pp. 387-395. Amsterdam, Nederland.

Hale, R.C., Alaee, M., Manchester-Neesvig, J.B., Stapleton, H.M. and Ikonomou, M.G. (2003). Polybrominated diphenyl ether flame retardants in the North American environment. Environment International, 29: 771-779.

Halls, S. (2000). Environmentally Sound Technologies for Wastewater and Stormwater Management. Japan, Newsletter and Technical Publications.

Hong, J., Jingmin, H., Otaki, M., and Jolliet, O. (2009). Environmental and economic life cycle assessment for sewage sludge treatment processes in Japan. Waste Management, 29: 696-703.

IPCC, (2006). IPCC Guidelines for national green house gas inventories.

Jamali, M.K., Kazi, T.G., Arain, M.B., Afridi, H.I., Jalbani, N., Baig, J.A. and Niaz, A. (2008). Effect of liming on the distribution of heavy metals in untreated industrial sewage sludge produced in Pakistan for the cultivation of Sorghum bicolor (L.). Environmentalist, 28: 366-375.

Javier Mateo-Sagasta, Liqa Raschid-Sally and Anne Thebo (2015). Global wastewater and sludge production, treatment and use. P. Drechsel et al. (eds.), Wastewater Economic Asset in an Urbanizing World, DOI 10.1007/978-94-017-9545-6 2

Khalid Usman, Sarfaraz Khan, Said Ghulam, Muhammad Umar Khan, Niamatullah Khan, Muhammad Anwar Khan and Shad Khan Khalil (2012). Sewage Sludge: An Important Biological Resource for Sustainable Agriculture and Its Environmental Implications. American Journal of Plant Sciences, 3: 1708-1721 http://dx.doi.org/10.4236/ajps.2012.312209.

Kubátová, P., Hejcman, M., Száková, J. Vondráčková, S. and Tlustoš, P. (2016). Effects of Sewage sludge application on biomass production and concentrations of $\mathrm{Cd}, \mathrm{Pb}$ and $\mathrm{Zn}$ in shoots of Salix and Populus clones: Improvement of phytoremediation efficiency in contaminated soils. Bioenergy Research, 9:809-819.

Kumar, V. and Chopra, A.K. (2012). Translocation of micronutrients in French bean (Phaseolus vulgaris L.) grown on soil amended with paper mill sludge. Journal of Chemical and Pharmaceutical Research, 4(11):4822-4829.

Kumar, V. and Chopra, A.K. (2013). Accumulation and translocation of metals in soil and different parts of French bean (Phaseolus vulgaris L.) amended with sewage sludge. Bulletin of Environmental Contamination and Toxicology, 92 (1): 103-108. DOI: 10.1007/s00128-013-1142-0

Kumar, V. and Chopra, A.K. and Srivastava, S. (2016). Assessment of heavy metals in spinach (Spinacia oleracea L.) grown in sewage sludge amended soil. Communications in Soil Science and Plant Analysis, 47(2): 221-236.DOI: 10.1080/00103624.2015.1122799.

Kumar, V. and Chopra, A.K. (2016a). Agronomical performance of high yielding cultivar of eggplant (Solanum melongena L.) grown in sewage sludge amended soil. Research in Agriculture, 1(1): 124.

Kumar, V. and Chopra, A.K. (2016b). Effects of sugarcane pressmud on agronomical characteristics of hybrid cultivar of eggplant (Solanum melongena L.) under field conditions. International Journal of Recycling of Organic Waste in Agriculture, 5: 149162, DOI 10.1007/s40093-016-0125-7.

Kumar, V., Singh, J. Pathak, V.V., Ahmad, S. and Kothari, R. (2017). Experimental and kinetics study for phytoremediation of sugar mill effluent using water lettuce (Pistia stratiotes L.) and its end use for biogas production. 3 Biotech, 7:330 DOI 10.1007/s13205-017-0963-7.

Leite Moretti, S.M. Bertoncini, E.I. Vitti, A.C., Alleoni, L.R.F. and Junior, C.H.A. (2016). Concentration of $\mathrm{Cu}, \mathrm{Zn}, \mathrm{Cr}, \mathrm{Ni}, \mathrm{Cd}$, and $\mathrm{Pb}$ in soil, sugarcane leaf and juice: residual effect of sewage sludge and organic compost application. Environmental Monitoring and Assessment, 188(3): 163, doi: 10.1007/s10661016-5170-1

Liang, Y., Nikolic, M., Peng, Y., Chen, W. and Jiang, Y. (2005). Organic manure stimulates biological activity and barley growth in soil subject to secondary salinization. Soil Biology and Biochemistry, 37: 1185-1195.

Liang, Y., Yang, Y., Yang, C., Shen, Q., Zhou, J. and Yang, L. (2003). Soil enzymatic activity and growth of rice and barley as influenced by organic manure in an anthropogenic soil. Geoderma, 115: 149-160.

Lue-Hing, C., Pietz, R.I., Granto, T.C., Gschwind, J. and Zenz, D.R. 1994. Overview of the Past 25 Years: Operator's Perspective. Pages 7-14 in C.E. Clapp, W.E. Larson, and R.H.Dowdy, editors. Sewage Sludge: land utilization and the environment. American Society of Agronomy, Inc., Crop Science Society of America, Inc., Soil Science Society of America, Inc. Madison, WI.

Lundin, M., Olofsson, M., Pettersson, G.J., and Zetterlund, H. (2004). Environmental and economic assessment of sewage sludge handling options. Resource, Conservation and Recycling, 41(4): 255-278.

McBride, M.B. Richards, B.K. and Steenhuis, T. (2004). Bioavailability and crop uptake of trace elements in soil columns amended with sewage sludge products. Plant and Soil, 262: 71-84.

Meena, R., Datta, S.P., Golui, D., Dwivedi, B.S., and Meena, M.C. (2016). Long-term impact of sewage irrigation on soil properties and assessing risk in relation to transfer of metals to human food chain. Environmental Science and Pollution Research, 23: 14269-14283.

Metcalf and Eddy, 1997. Wastewater Engineering, Treatment, Disposal and Reuse. McGraw Hill, New York.

Ning-Yi Wang, Chun-Hao Shih, Pei-Te Chiueh and Yu-Fong Huang (2013). Environmental effects of sewage sludge carbonization and other treatment alternatives. Energies, 6: 871-883.

Nogueirol, R.C., De Melo, W.J. Bertoncini, E.I. and Alleoni, L.R.F. (2013). Concentrations of $\mathrm{Cu}, \mathrm{Fe}, \mathrm{Mn}$, and $\mathrm{Zn}$ in tropical soils amended with sewage sludge and composted sewage sludge. Environmental Monitoring and Assessment, 185:2929-2938.

Pakhnenkoa, E.P., Ermakova, A.V. and Ubugunovb, L.L. (2009). Influence of sewage sludge from sludge beds of Ulan Ude on the soil properties and the yield and quality of potatoes. Moscow University Soil Science Bulletin, 64(4): 175-181.

Pöschl, M., Ward, S. and Owende, P. (2010). Evaluation of energy efficiency of various biogas production and utilization pathways. Applied Energy, 87(11): 3305-3321.

Poulsen, T.G., and Hansen, J.Aa. (2003). Strategic environmental assessment of alternative sewage sludge management scenarios. Department of Environmental Engineering, Aalborg University.

Ramachandran, V. and D'Souza, T.J. (1998). Plant uptake of cadmium, zinc, and manganese in soils amended with sewage sludge and city compost. Bulletin of Environmental Contamination and Toxicology, 61: 347-354.

Rodr1'guez, A.R. Castro, S. and Losada, M.R.M. (2010). Effects of dose and period of sewage sludge application on soil tree and pasture components in a Pinus radiata D. Don silvopastoral 
system. Agroforestry System, 79:237-247, DOI 10.1007/s10457010-9281-3

Rogers, H. (2012). Perspectives for biogas in Europe. UK, Oxford Institute for Energy Studies.

Selivanovskaya, S.Y., Latypova, V.Z. and Gubaeva, L.A. (2006). Microbiological processes in gray forest soil treated with sewage sludge compost. Eurasian Soil Science, 39(4): 443-449.

Sellstrom, U., Kierkegaard, A., Alsberg, T., Jonsson, P. and de Wit, C. (1999). Organohalogen Compound. 40: 383.

Shahbazi, F., Ghasemi, S., Sodaiezadeh, H., Ayaseh, K. and Ahmadmahmoodi, R.Z. (2017). The effect of sewage sludge on heavy metal concentrations in wheat plant (Triticum aestivum L.). Environmental Science and Pollution Research, 24:1563415644.

Shrivastava, S.K. and Banerjee, D.K. (2003). Speciation of metals in sewage sludge and sludge amended soils. Water, Air, and Soil Pollution, 152: 219-232.

Sigua, G.C. Adjei, M.B. and Rechcigl, J.E. (2005). Cumulative and residual effects of repeated sewage sludge applications: forage productivity and soil quality implications in South Florida, USA. Environmental Science and Pollution Research, 12(2): 80-88.

Sikka, R., Nayyar, V. and Sidhu, S.S (2009). Monitoring of Cd pollution in soils and plants irrigated with untreated sewage water in some industrialized cities of Punjab, India. Environmental Monitoring and Assessment, 154: 53-64.

Spinosa, L. (2008). Status and perspectives of sludge management. UK, CNR.

Tejada, M., Garcia, C., Gonzalez, J.L. and Hernandez, M.T. (2006). Use of organic amendment as a strategy for saline soil remediation: influence on the physical, chemical and biological properties of soil. Soil Biology and Biochemistry, 38: 1413-1421.

Turovskiy, I.S. and Mathai, P.K. (2006). Wastewater sludge processing. John Wiley \& Sons, New Jersey, USA.

Tziachris, P., Lekakis, P., Zambetoglou, K., Metaxa, I. and Papado- poulos, F. (2017). A case study of the effects of sewage sludge application on soil properties and heavy metal availability in the Thessaloniki Plain (Greece). Waste and Biomass Valorization, 8: 1803-1811.

Ullah, H. and Khan, I. (2015). Effects of sewage water irrigation of cabbage to soil geochemical properties and products safety in periurban Peshawar, Pakistan. Environmental Monitoring and Assessment, 187: 126, doi: 10.1007/s10661-015-4344-6.

Ullah, H., Khan, N.U., Ali, F., Shah, Z.A. and Ullah, Q. (2017). Health risk of heavy metals from vegetables irrigated with sewage water in peri-urban of Dera Ismail Khan, Pakistan. International Journal of Environmental Science and Technology, DOI 10.1007/s13762-017-1384-1.

Walker, J.M. (1994). Production, use, and creative design of sewage sludge biosolids. Pages $67-74$ in C.E. Clapp, W.E. Larson, and R.H. Dowdy, editors. Sewage Sludge: land utilization and the environment. American Society of Agronomy, Inc., Crop Science Society of America, Inc., Soil Science Society of America, Inc. Madison, WI.

Walker, D.J. and Bernal, M.P. (2008). The effects of olive mill waste compost and poultry manure on the availability and plant uptake of nutrients in a highly saline soil. Bioresource Technology, 99: 396-403.

Williams, P.T. (2005). Waste treatment and disposal. UK, John Wiley \& Sons.

$\mathrm{Xu}$, A. (2014). Biogas from sewage sludge-Safe disposal of sewage sludge in the People's Republic of China. University of Rostock, Justus-von-Liebig-Weg 6, D 18051 Rostock.

$\mathrm{Xu}, \mathrm{G}$. (2014). Analysis of sewage sludge recovery system in EU in perspectives of nutrients and energy recovery efficiency, and environmental impacts. Norwegian University of Science and Technology. pp: 88 .

Zhang, H. (2010). Sludge treatment to increase biogas production. Trita-LWR Degree Project 10-20, Sweden. 